\title{
KONTRIBUSI KEMAMPUAN BERPIKIR ANALISIS DAN KREATIVITAS TERHADAP PRESTASI BELAJAR SISWA PADA MATERI POKOK LARUTAN ELEKTROLIT DAN NON- ELEKTROLIT KELAS X MIA SMA NEGERI KEBAKRAMAT TAHUN PELAJARAN 2016/2017
}

\author{
Dewi Sandianita ${ }^{\star}$, Nurma Yunita Indriyanti, dan Bakti Mulyani \\ Program Studi Pendidikan Kimia, FKIP, Universitas Sebelas Maret, Surakarta, Indonesia \\ *Untuk korespondensi, HP: 085642131957, e-mail: dewi.sandianita@gmail.com
}

\begin{abstract}
ABSTRAK
Tujuan dari penelitian ini adalah untuk mengetahui ada atau tidak hubungan antara kemampuan berpikir analisis dengan prestasi belajar siswa, ada atau tidak hubungan antara kreativitas dengan prestasi belajar siswa, ada atau tidak hubungan antara kemampuan berpikir analisis dan kreativitas secara bersama-sama dengan prestasi belajar siswa pada materi pokok Larutan Elektrolit dan Non-Elektrolit. Sampel dalam penelitian ini adalah siswa kelas X IPA SMA yang ada di Kebak Kramat tahun ajaran 2016/2017. Penelitian ini menggunakan metode korelasional. Teknik pengumpulan data menggunakan metode tes untuk mengukur pengetahuan dan kemampuan berpikir analisis serta kreativitas. Uji hipotesis dilakukan menggunakan ANAVA dua jalan dengan bantuan aplikasi SPSS 18. Teknik pengumpulan data yang dilaksanakan berupa analisa hasil tes. Berdasarkan hasil analisis dapat disimpulkan: (1) Terdapat hubungan yang signifikan antara kemampuan berpikir analisis dengan prestasi belajar pada materi larutan elektrolit dan non-elektrolit, dari uji t-dua pihak diperoleh nilai signifikansi (p) 0,000 dan koefisien korelasi Pearson 0,213 (2) Terdapat hubungan yang signifikan antara kreativitas dengan prestasi belajar pada materi larutan elektrolit dan non-elektrolit, dari uji t-dua pihak diperoleh nilai signifikansi (p) 0,000 dan koefisien korelasi Pearson 0,681. (3) Terdapat hubungan yang signifikan antara kemampuan berpikir analisis dan kreativitas dengan prestasi belajar pada materi larutan elektrolit dan non-elektrolit, dari uji $F$ diperoleh nilai signifikansi (p) 0,000 dan koefisien korelasi ganda $0,708, \mathrm{R} 2$ sebesar 0,300 .
\end{abstract}

Kata Kunci : Kemampuan Berpikir Analisis, Kreativitas, Prestasi Belajar

\section{PENDAHULUAN}

Pendidikan merupakan proses untuk membantu manusia dalam mengembangkan dirinya sehingga mampu menghadapi setiap perubahan yang terjadi. Dewasa ini pendidikan dan pengajaran di Indonesia menunjukkan perkembangan yang cukup pesat. Pemerintah secara bertahap dan terusmenerus berusaha meningkatkan kualitas dan kuantitas pendidikan yang ada di Indonesia. Upaya pemerintah dalam meningkatkan kualitas dengan peningkatan sarana dan prasarana, perubahan kurikulum dan proses belajar mengajar, peningkatan kualitas guru, dan usaha lain yang tercakup dalam komponen pendidikan. Hal ini menunjukkan bahwa dukungan pemerintah terhadap pendidikan nasional sangat besar.

Upaya peningkatan mutu pendidikan telah lama dilakukan, salah satunya adalah dengan mengadakan perombakan dan pembaharuan kurikulum yang berkesinambungan, mulai dari kurikulum 1947 sampai kurikulum 2004. Pada tahun 2006, kurikulum mengalami pembaharuan yaitu Kurikulum Tingkat Satuan Pendidikan (KTSP). Kurikulum Tingkat Satuan Pendidikan (KTSP) adalah penyempurna kurikulum sebelumnya yakni Kurikulum Berbasis Kompetensi (KBK). Kurikulum Tingkat Satuan Pendidikan (KTSP) adalah 
kurikulum operasional yang disusun oleh dan dilaksanakan di masing-masing satuan pendidikan yang terdiri dari tujuan pendidikan Tingkat Satuan Pendidikan, kalender pendidikan, dan silabus

Faktor-faktor yang mempengaruhi prestasi belajar diantaranya adalah faktor internal dan faktor eksternal. Faktor internal adalah faktor yang timbul dari dalam diri individu siswa itu sendiri. Adapun yang dapat digolongkan ke dalam faktor internal adalah kecerdasan / intelegensi, fisiologis, sikap, minat, bakat, motivasi, kemampuan berpikir analisis, dan kreativitas. Sedangkan faktor eksternal adalah faktor-faktor yang dapat mempengaruhi prestasi belajar yang sifatnya dari luar diri siswa. Faktor eksternal ini meliputi media pembelajaran, model pembelajaran, keadaan sekolah, keadaan keluarga, dan lingkungan masyarakat.

\section{METODE PENELITIAN}

Metode penelitian yang digunakan dalam penelitian ini adalah metode korelasional. Metode ini mencoba untuk mencari ada dan tidak hubungan antara kemampuan berpikir analisis dan kreativitas dengan prestasi belajar. Terdapat dua variabel terikat. Untuk lebih jelanya dapat dilihat dalam Tabel1. [3].

Tabel 1. Desain Penelitian

\begin{tabular}{cccc}
\hline $\mathbf{Y}$ & $\mathrm{X}_{1}$ & $\mathrm{X}_{2}$ & $\mathrm{X}_{1} \mathrm{X}_{2}$ \\
\hline $\mathbf{Y}$ & $\mathrm{X}_{1} \mathrm{Y}$ & $\mathrm{X}_{2} \mathrm{Y}$ & $\mathrm{X}_{1} \mathrm{X}_{2} \mathrm{Y}$ \\
\hline
\end{tabular}

Keterangan :

$\mathrm{X}_{1} \quad$ : kemampuan berpikir analisis

$\mathrm{X}_{2} \quad$ : kreativitas

$\mathrm{X}_{1} \mathrm{Y}$ : korelasi kemampuan berpikir analisis terhadap prestasi belajar

$\mathrm{X}_{2} \mathrm{Y}$ : korelasi kreativitas terhadap prestasi belajar
Sampel penelitian adalah siswa kelas X semester 2 Sekolah Menengah Atas di Kebak Kramat secara purposive random sampling. Dalam hal ini dipilih berdasarkan tingkat kualifikasi kelas di SMA Kebak Kramat

Pengumpulan data dilakukan melalui satu cara, yaitu: metode tes. Tes yang dilakukan ini adalah tes pengukuran seberapa tinggi tingkat kemampuan berpikir analisis, kreativitas, serta prestasi belajar siswa .

Instrumen pengambilan data meliputi instrumen penilaian pengetahuan kemampuan berpikir analisis dan kreativitas. Teknik analisis instrumen pengetahuan menggunakan : (1) Uji validitas menggunakan formula Gregory [8] dinyatakn valid, (2) Uji reabilitas untuk hasil uji coba instrumen dengan bantuan SPSS 18 dinyatakan reliabel dengan harga reliabilitas 0,730 , (3) Uji tingkat kesukaran untuk hasil uji coba instrumen diperoleh hasil dari 20 soal yang diuji cobakan, 3 soal tergolong sedang dan 17 soal tergolong mudah, (4) Uji daya beda soal untuk hasil dari 20 soal, 2 soal tergolong jelek, 10 soal tergolong sedang, dan 8 soal tergolong baik.

Uji prasyarat analisis yang dilakukan adalah uji normalitas, dan uji homogenitas. Sedangkan teknik analisis data menggunakan uji analisis regresi linearitas berganda. Uji prasyarat analisis dan uji hipotesis dalam penelitian ini dilakukan dengan bantuan SPSS 18.

\section{HASIL DAN PEMBAHASAN}

Dari penelitian yang telah dilakukan, uji prasyarat analisis

\section{Uji Normalitas}

Uji Normalitas. Data mengenai prestasi belajar siswa, kemampuan berpikir analisis, dan kreativitas yang dianalisis menggunakan uji kolmogorov Smirnov. Ringkasan hasil uji normalitas disajikan dalam Tabel 2. 
Tabel 2. Tabel Normalitas Semua Variabel

Tests of Normality

\begin{tabular}{|l|r|r|r|r|r|r|}
\hline & \multicolumn{3}{|c|}{ Kolmogorov-Smirnov a } & \multicolumn{3}{c|}{ Shapiro-Wilk } \\
\cline { 2 - 7 } & Statistic & \multicolumn{1}{|c|}{$\mathrm{df}$} & \multicolumn{1}{c|}{ Sig. } & Statistic & \multicolumn{1}{c|}{ df } & \multicolumn{1}{c|}{ Sig. } \\
\hline Prestasi & .175 & 72 & .000 & .956 & 72 & .013 \\
Analisis & .071 & 72 & $.200 *$ & .989 & 72 & .781 \\
Kreatifitas & .132 & 72 & .003 & .970 & 72 & .082 \\
\hline
\end{tabular}

a. Lilliefors Significance Correction

*. This is a lower bound of the true significance.

Tampak dari Tabel diatas bahwa dari hasil perhitungan menggunakan SPSS diketahui signifikansi kemampuan berpikir Analisis > 0,05, dengan demikian dapat dikatakan bahwa variable tersebut berdistribusi normal. Sebaliknya signifikansi untuk variable Prestasi Belajar dan Kreatifitas $<0,05$ sehingga variable tersebut tidak berdistribusi normal. Pengumpulan data tentang kemampuan berpikir analisis adalah dengan menggunakan instrumen.

\section{Uji Independensi}

Uji Independensi. Uji independensi disebut juga uji multikolinearitas. Multikolinearitas adalah keadaan dimana dua variabel saling independen. Adanya multikolinearitas menyebabkan pengaruh masing-masing variabel independen sulit dideteksi. Untuk menguji independensi dilakukan dengan dua cara. Cara pertama melihat nilai VIF (Faktor Varian Inflasi) yang tertera pada hasil output pada analisis yang menggunakan SPSS 18 atau dengan menggunakan rumus Korelasi Pearson. Ringkasan hasil uji independensi tercantum pada Tabel 3.

Tabel 3. Tabel Multikolinearitas

\begin{tabular}{cccc}
\hline No & Variabel & VIF & \multicolumn{1}{c}{ Kesimpulan } \\
\hline 1 & $\begin{array}{l}\text { Kemampuan } \\
\text { Analisis }\end{array}$ & 1,001 & $\begin{array}{l}\text { Tidak terjadi } \\
\text { multikolinearitas }\end{array}$ \\
2 & Kreatifitas & 1,001 & $\begin{array}{l}\text { Tidak terjadi } \\
\text { multikolinearitas }\end{array}$ \\
\hline
\end{tabular}

Hasil uji dikatakan independen bila signifikansi > 0,05. Berdasarkan Tabel 3. diatas dapat dilihat bahwa hubungan antara variabel-variabel nilai signifikansi $>0,05$, sehingga dapat disimpulkan bahwa tidak ada hubungan antara variabel-variabel tersebut atau saling independen. Cara kedua adalah dengan menggunakan rumus korelasi Pearson. Hasil uji dengan rumus Karl Pearson tercantum dalam Tabel 4.

Tabel 4 Uji Independensi

\begin{tabular}{ccc}
\hline No & Variabel & $\begin{array}{c}\text { Sig. Korelasi } \\
\text { Pearson }\end{array}$ \\
\hline 1 & $\begin{array}{c}\text { Kemampuan Analisis } \\
\text { dan Kreatifitas }\end{array}$ & 0,28 \\
\hline
\end{tabular}

Hasil uji dikatakan independen bila signifikansi > 0,05. Berdasarkan Tabel 4 . diatas dapat dilihat bahwa hubungan antara variabel-variabel nilai signifikansi $>0,05$, sehingga dapat disimpulkan bahwa tidak ada hubungan antara variabel - variabel tersebut atau saling independen.

\section{Uji Heterokedastisitas}

Heterokedastisitas adalah keadaan dimana terjadinya ketidaksamaan varian dari residual pada model regresi. Model regresi yang baik mensyaratkan tidak adanya masalah heterokedastisitas karena akan menyebabkan estimator tidak efisien dan nilai koefisien determinasi menjadi sangat tinggi.

Untuk mendeteksi ada tidaknya heterokedastisitas adalah dengan melihat pola titik-titik pada gambar. Jika titik- titik menyebar dengan pola yang tidak jelas di atas dan di bawah angka 0 pada sumbu $\mathrm{Y}$, maka tidak terjadi masalah heterokedastisitas.

Selain dengan metode grafik, uji ini juga dapat dilakukan dengan Uji Glejser. Hasil uji dengan SPSS. Dari perhitungan SPSS diperoleh hasil yang dapat dilihat pada Tabel 5. 
Tabel 5. Hasil Uji Heterokedastisitas

\begin{tabular}{|c|c|c|c|c|c|}
\hline \multirow[t]{2}{*}{ Model } & \multicolumn{2}{|c|}{$\begin{array}{l}\text { Unstandardize } \\
\text { d Coefficients }\end{array}$} & \multirow{2}{*}{$\begin{array}{c}\begin{array}{c}\text { Standar } \\
\text { dized } \\
\text { Coeffici } \\
\text { ents }\end{array} \\
\text { Beta }\end{array}$} & \multirow[t]{2}{*}{$\mathrm{t}$} & \multirow[t]{2}{*}{ Sig. } \\
\hline & B & $\begin{array}{l}\text { Std. } \\
\text { Error }\end{array}$ & & & \\
\hline Constant) & 3,320 & 10,505 & & ,316 & ,753 \\
\hline 1 Analisis & 240 & 105 & 194 & 2,276 & ,026 \\
\hline Kreativitas & 1,565 & ,197 & 675 & 7,934 &, 000 \\
\hline
\end{tabular}

Dari Tabel 5 nilai t tidak ada yang signifikan karena signifikansi pada variabel-variabel $>0,05$, sehingga disimpulkan tidak ada masalah heterokedastisitas.

\section{Uji Linearitas Regresi}

Uji asumsi selanjutnya untuk regresi linear berganda adalah uji linearitas. Uji linearitas dilakukan antara kemampuan berpikir analisis dengan prestasi, kreativitas dengan prestasi.

\section{a. Uji Linearitas Kemampuan Berpikir Analisis (X1) terhadap Prestasi Belajar Siswa (Y)}

Uji linearitas pertama adalah antara kemampuan berpikir analisis dan prestasi siswa. Hasil output uji linearitas dengan menggunakan SPSS dapat dilihat pada pada Tabel 6 .

Tabel 6. Hasil Uji Linearitas Kemampuan Berpikir Analisis dengan Prestasi Belajar Siswa

\begin{tabular}{lccccccc}
\hline & & $\begin{array}{c}\text { Sum of } \\
\text { Squares }\end{array}$ & df & $\begin{array}{c}\text { Mean } \\
\text { Square }\end{array}$ & $F$ & Sig. \\
& & $\begin{array}{c}\text { (Combin } \\
\text { ed) }\end{array}$ & 2422,431 & 30 & 80,748 & 1,056 &, 430 \\
PR & & & 251,27 & 3,286 &, 077 \\
ES & $\begin{array}{c}\text { Between Linearity } \\
\text { TA }\end{array}$ & 251,278 & 1 & 8 & & \\
SI * & $\begin{array}{c}\text { Groups } \begin{array}{c}\text { Deviation } \\
\text { from } \\
\text { AN }\end{array} \\
\text { ALI }\end{array}$ & 2171,153 & 29 & 74,867 &, 979 &, 517 \\
SIS & Winearity & & & & & \\
\cline { 2 - 8 } & Within Groups & 3135,556 & 41 & 76,477 & & \\
\hline
\end{tabular}

Dari Tabel 6 dapat dilihat bahwa signifikansi pada penyimpangan dari linearitas (Deviation from Linearity) adalah 0,517. Bila signifikansi $>0,05$, maka dapat disimpulkan bahwa model regresi antara kemampuan berpikir analisis dan prestasi belajar bersifat linear.

\section{b. Uji Linearitas Kreativitas (X2) terhadap Prestasi Belajar Siswa (Y)}

Uji linearitas selanjutnya adalah antara kreativitas dengan prestasi belajar. Rangkumannya dapat dilihat pada Tabel 7.

Tabel 7. Hasil Uji Linearitas kreativitas dengan Prestasi Belajar

\begin{tabular}{|c|c|c|c|c|c|c|c|}
\hline & & & $\begin{array}{l}\text { Sum of } \\
\text { Squares }\end{array}$ & $\mathrm{df}$ & $\begin{array}{l}\text { Mean } \\
\text { Square }\end{array}$ & $\mathrm{F}$ & Sig. \\
\hline \multirow{5}{*}{$\begin{array}{c}\text { PR } \\
\text { EST } \\
\text { ASI } \\
* \\
\text { KR } \\
\text { EAT } \\
\text { IVIT } \\
\text { AS }\end{array}$} & \multirow{3}{*}{$\begin{array}{c}\text { Betwe } \\
\text { en } \\
\text { Grou } \\
\text { ps }\end{array}$} & (Combined & ) 3542,639 & 16 & 225,436 & 6,043 &, 000 \\
\hline & & Linearity & 2574,793 & 1 & 2574,793 & 70,268 &, 000 \\
\hline & & $\begin{array}{c}\text { Deviation } \\
\text { from } \\
\text { Linearity }\end{array}$ & 967,846 & 15 & 64,523 & 1,761 & ,065 \\
\hline & \multicolumn{2}{|c|}{ Within Groups } & 2015,347 & 55 & 36,643 & & \\
\hline & \multicolumn{2}{|r|}{ Total } & 5557,986 & 71 & & & \\
\hline
\end{tabular}

Dari Tabel 7 dapat dilihat bahwa signifikansi pada penyimpangan dari linearitas (Deviation from Linearity) adalah 0,065. Bila signifikansi > 0,05, maka dapat disimpulkan bahwa model regresi antara kreativitas dan prestasi belajar bersifat linear.

\section{Uji Hipotesis}

Setelah uji asumsi dalam regresi linear berganda terpenuhi, maka ,dilakukan uji korelasi baik secara serentak maupun secara sendiri-sendiri untuk mengetahui ada tidaknya pengaruh korelasi positif yang signifikasn antara variabel-variabel bebas dengan variabel terikat. Selanjutnya dilakukan uji regresi linear berganda.

Tabel 8. Hasil Uji t-dua pihak

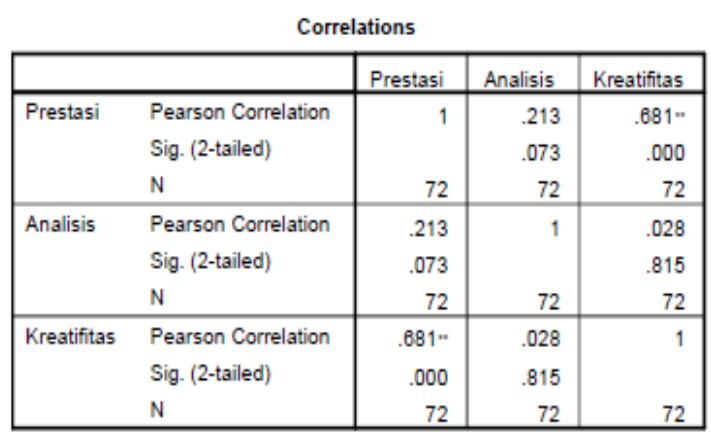

$"$ ". Correlation is significant at the 0.01 level (2-tailed). 


\section{a. Uji Hipotesis Pertama}

Dari Tabel 8 dapat dilihat bahwa hasil signifikansi uji t-dua pihak antara kemampuan analisis dengan prestasi belajar siswa adalah 0,073. Karena signifikansi > 0,050 maka HO diterima, sehingga disimpulkan bahwa hubungan yang ada tidak signifikan antara kemampuan berpikir analisis dengan prestasi belajar siswa. Koefisien korelasi antara kemampuan berpikir analisis dengan prestasi adalah 0,213 yang mempunyai arti bahwa ada korelasi positif yang rendah antara kemampuan berpikir analisis dengan prestasi belajar siswa. Dengan demikian dari uji hipotesis pertama disimpulkan bahwa ada korelasi positif yang rendah antara kemampuan berpikir analisis dengan prestasi belajar siswa.

\section{b. Uji Hipotesis Kedua}

Dari Tabel 8. dapat dilihat bahwa hasil signifikansi uji t-dua pihak antara kreativitas dengan prestasi belajar siswa adalah 0,000. Karena signifikansi $<0,050$ maka $\mathrm{H}_{0}$ ditolak, sehingga disimpulkan bahwa ada hubungan yang signifikan antara kreativitas dengan prestasi belajar siswa.

Setelah diketahui ada hubungan yang signifikan antara kreativitas dengan prestasi belajar siswa, maka dari Tabel 8. dapat dilihat bahwa koefisien korelasi antara kreativitas dengan prestasi adalah 0,681 yang menunjukkan bahwa ada korelasi positif yang cukup kuat antara kreativitas dengan prestasi belajar siswa. Dengan demikian dari uji hipotesis kedua disimpulkan bahwa ada korelasi positif yang signifikan antara kreativitas dengan prestasi belajar siswa.

\section{c. Uji Hipotesis Ketiga}

Dari Tabel 8 dapat dilihat bahwa nilai $F$ hitung $(34,602)>F$ tabel $(1,67)$ sehingga disimpulkan bahwa ada hubungan kemampuan berpikir analisis, kreativitas secara bersama-sama berpengaruh terhadap prestasi belajar siswa.

\section{d. Uji Koefisien dan Keberartian Model Regresi Linear}

Tabel 9. Hasil Uji Koefisien dan Keberartian Model Regresi Linear

\section{Coefficients $^{\mathrm{a}}$}

\begin{tabular}{|c|c|c|c|c|c|}
\hline \multirow[t]{2}{*}{ Model } & \multicolumn{2}{|c|}{$\begin{array}{c}\text { Unstandardized } \\
\text { Coefficients }\end{array}$} & $\begin{array}{c}\text { Standar } \\
\text { dized }\end{array}$ & \multirow[t]{2}{*}{$\mathrm{T}$} & \multirow[t]{2}{*}{ Sig. } \\
\hline & $B$ & $\begin{array}{l}\text { Std. } \\
\text { Error }\end{array}$ & Beta & & \\
\hline $\begin{array}{l}\text { (Cons } \\
\text { tant) }\end{array}$ & 33.635 & 14.263 & & $\begin{array}{r}2.35 \\
8\end{array}$ & .021 \\
\hline $\begin{array}{l}\text { Anali } \\
\text { sis }\end{array}$ & -.019 & .129 & -.015 & $\begin{array}{r}-.14 \\
7\end{array}$ & .883 \\
\hline $\begin{array}{l}\text { Kreati } \\
\text { vitas }\end{array}$ & 1.277 & .242 & .544 & $\begin{array}{r}5.28 \\
9\end{array}$ & .000 \\
\hline
\end{tabular}

a. Dependent Variable: Prestasi

Dari Tabel 9 nilai B merupakan koefisien-koefisien yang ada pada model regresi, sedangkan nilai $t$ atau signifikansi dapat digunakan untuk menentukan apakah koefisien regresi tersebut signifikan atau tidak. Dari tabel dapat diketahui bahwa model yang didapatkan yaitu:

$$
Y=33,635-0,19 X 1+1,277 X 2
$$

Untuk mengetahui koefisien regresi dari masing-masing variabel signifikan atau tidak, cukup dilihat nilai signifikansi bila nilai signifikansi $<0,05$, maka dapat disimpulkan bahwa koefisien regresi signifikan. Dari Tabel 9 dapat dilihat bahwa nilai signifikansi pada Kemampuan Berpikir Analisis dan Kreativitas siswa semuanya $<0.05$, sehingga disimpulkan bahwa seluruh koefisien regresi yang didapat signifikan.

Persamaan regresi tersebut berarti

1) Konstanta $b_{0}=33,635$ artinya jika kemampuan berpikir analisis dan kreativitas siswa nilainya 0 , maka prestasi siswa nilainya positif sebesar 33,635.

2) Konstanta $b_{1}=-0,19$ artinya jika kreativitas siswa nilainya tetap, sedangkan kemampuan berpikir analisis nilainya ditingkatkan 1 maka prestasi siswa akan menurun sebesar $-0,19$. 
3) Konstanta $b_{2}=1,277$ artinya jika kemampuan berpikir analisis siswa nilainya tetap, sedangkan kreativitas nilainya ditingkatkan 1 maka prestasi siswa akan meningkat sebesar 1,277.

Bila persamaan regresi telah diperoleh, maka sumbangan efektif dan sumbangan relatif dari masing-masing variabel dapat dihitung. Sedangkan rangkuman sumbangan setiap variabel dapat dilihat pada Tabel 10.

Tabel 10. Sumbangan Efektif dan Sumbangan Relatif Variabelvariabel Bebas terhadap Prestasi Belajar Siswa

\begin{tabular}{ccc}
\hline Variabel & $\begin{array}{c}\text { Sumbangan } \\
\text { Efektif }(\%)\end{array}$ & $\begin{array}{c}\text { Sumbangan } \\
\text { Relatif }(\%)\end{array}$ \\
\hline $\begin{array}{c}\text { Kemampuan } \\
\text { Berpikir } \\
\text { Analisis }\end{array}$ & 1,93 & 6,43 \\
Kreativitas & 28,07 & 93,57 \\
\hline Jumlah & 30 & 100 \\
\hline
\end{tabular}

Dari Tabel 10 dapat diinterpretasikan bahwa kontribusi kemampuan berpikir analisis dan kreativitas siswa terhadap prestasi belajar siswa adalah $30 \%$, sedangkan sisanya $70 \%$ dipengaruhi variabel lain yang tidak diteliti. Kemudian dapat dilihat bahwa sumbangan efektif maupun relatif dari kemampuan berpikir analisis < kreativitas.

Sumbangan efektif merupakan sumbangan variabel yang diteliti dilihat dari keseluruhan variabel termasuk yang tidak diteliti. Sumbangan efektif Kemampuan berpikir analisis yaitu $1,93 \%$ dan kreativitas $28,07 \%$. Kreativitas paling berkontribusi dibandingkan dengan kemampuan berpikir analisis dengan nilai sumbangan relatif $93,57 \%$ sedangkan sumbangan relatif dari kemampuan berpikir analisis yaitu sebesar 6,43\%. Hal ini terjadi karena prestasi yang diteliti adalah prestasi siswa pada materi larutan elektrolit dan non-elektrolit kelas $X$ yang membutuhkan kreativitas, sehingga kreativitas paling berpengaruh dibandingkan variabel yang lain. Sedangkan kemampuan berpikir analisis sumbangan efektifnya hanya sebesar $1,93 \%$ hal tersebut menunjukkan bahwa berpikir analisis memberikan pengaruh kecil terhadap prestasi belajar materi larutan elektrolit dan non-elektrolit. Hal ini terjadi karena prestasi yang diteliti adalah prestasi siswa pada materi larutan elektrolit dan non-elektrolit kelas $X$ tidak terlalu membutuhkan kemampuan berpikir analisis. Sehingga dapat disimpulkan bahwa yang berkontribusi pada prestasi belajar materi larutan elektrolit dan non-elektrolit adalah kreativitas sedangkan kemampuan berpikir analisis hanya memberikan kontribusi yang kecil terhadap prestasi belajar larutan elektrolit dan non-elektrolit.

\section{KESIMPULAN}

Berdasarkan kajian teori dan didukung adanya hasil analisis serta mengacu pada perumusan masalah yang telah diuraikan pada bab sebelumnya, dapat disimpulkan sebagai berikut:

Terdapat korelasi yang rendah antara kemampuan berpikir analisis dengan prestasi belajar siswa pada materi pokok larutan elektrolit dan nonelektrolit kelas X MIA 2 dan X MIA 4 SMA Negeri Kebak Kramat tahun pelajaran 2016/2017 dengan indeks korelasi 0,213, bentuk korelasi positif yang rendah, semakin tinggi kemampuan berpikir analaisis maka prestasi belajar siswa cenderung semakin tinggi.

Terdapat korelasi antara kreativitas dengan prestasi belajar siswa pada materi pokok larutan elektrolit dan nonelektrolit kelas X MIA 2 dan X MIA 4 SMA Negeri Kebak Kramat tahun pelajaran 2016/2017 dengan indeks korelasi 0,681, bentuk korelasi positif, semakin tinggi kreativitas maka prestasi belajar siswa cenderung semakin tinggi.

Terdapat korelasi antara kemampuan berpikir analisis dan kreativitas bersama-sama terhadap prestasi belajar siswa pada materi pokok larutan elektrolit dan non-elektrolit kelas X MIA 2 dan X MIA 4 SMA Negeri Kebak Kramat tahun pelajaran 2016/2017 dengan indeks korelasi 0,708 , bentuk korelasi positif, semakin tinggi kemampuan berpikir 
analisis dan kreativitas maka prestasi belajar siswa cenderung semakin tinggi.

Sumbangan kemampuan berpikir analisis dan prestasi belajar terhadap prestasi belajar siswa, berdasarkan pembahasan yang telah disampaikan adalah:

1. Sumbangan efektif kemampuan berpikir analisis $=1,93 \%$

2. Sumbangan relatif kemampuan berpikir analisis $=6,43 \%$

3. Sumbangan efektif kreativitas= $28,07 \%$

4. Sumbangan relatif kreativitas= 93,57\%

Prestasi belajar siswa tersebut dapat diprediksi dari kemampuan berpikir analisis dan kreativitas melalui regresi $Y=$ $33,635-0,19 X_{1}+1,277 X_{2}$.

\section{UCAPAN TERIMAKASIH}

Bapak Jaka Wismono S.Pd., M.Pd. selaku kepala sekolah SMA Kebak Kramat yang telah memberi ijin peneliti dan Ibu Ida Mariani selaku guru mata pelajaran kimia yang telah mengijinkan penulis menggunakan kelas untuk penelitian.

\section{DAFTAR RUJUKAN}

[1] Pemerintah Republik Indonesia. "Undang-Undang Republik Indonesia Nomor 20 Tahun 2003 Tentang Sistem Pendidikan Nasional." Indonesia, 8 Juli 2003.

[2] Kemendikbud. "Peraturan Menteri Pendidikan Pendidikan dan Kebudayaan Republik Indonesia Nomor 69 Tahun 2013 Tentang Kerangka Dasar Dan Struktur Kurikulum Sekolah Menengah Atas/Madrasah Aliyah." Indonesia, 2013.

[3] Chandrasegaran, A.L., treagust, D.F., \& Mocerino, M. (2008). An Evaluation of a Teaching Intervention to Promote Student's Ability to Use Multiple Level of Representation When Describing and Explaining Chemical Reactions. Res. Sci. Educ., 38 (2), 237-248.
[4] Sugiyono. Metode Penelitian Kuantitatif Kualitatif dan $R \& D$. Bandung: Alfabeta, 2009.

[5] T. C. Reeves. "How do You Know They are Learning?. The Importance of Alignment in Higher Education." International Journal Learning Technology, Vol, 2 (4): 294-309, 2006.

[6] J. A. Ross. "Reliability, Validity, and Utility of Self-Assessment." Practical Assessment Research \& Evaluation, Vol. 11 (10), 2006.

[7] G. Thomas, D. Martin, \& K. Pleasants. "Using Self- and Peerassessment to Enhance Student's Future Learning in Higher Education." Journal of University Teaching \& Learning Practice, Vol. 8 (1), 2011.

[8] H. Fry, S. Ketteridge, \& S. Marshall. A Handbook for Teaching and Learning in Higher Education. New York : Routledge, 2009.

[9] Munandar. Pengembangan Kreativitas Anak Berbakat. Jakarta: Rineka Cipta, 2004.

[10] Direktorat Jenderal Pendidikan Dasar dan Menengah. Panduan Penilaian untuk Sekolah Menengah Atas. Jakarta: Kemendikbud, 2017. 